\title{
Definition of the Total Antioxidant Capacity and Vitamin D Levels in Professional Athletes Who Play Football in Giresunspor
}

\author{
$\operatorname{Irem~Bahar~}^{1(\underline{(I D)})}$, Aysegul Cebi ${ }^{2(\mathbb{I D})}$ \\ ${ }^{1}$ Department of Medical Biochemistry, Institute of Health Sciences, Giresun University, Giresun, Turkey \\ ${ }^{2}$ Department of Midwifery, Faculty of Health Sciences, Giresun University, Giresun, Turkey
}

Copyright@ Author(s) - Available online at https://dergipark.org.tr/en/pub/mbsjohs Content of this journal is licensed under a Creative Commons Attribution-NonCommercial 4.0 International License,

Received: 07 Januvary 2021, Accepted: 29 March 2021, Published online: 30 April 2021

(C) Ordu University Institute of Health Sciences, Turkey, 2021

\begin{abstract}
Objective: A sufficient amount of vitamin D levels; while protein synthesis, muscle strength, jumping height, speed, exercise capacity, and physical performance increase; stress fractures cause a decrease in the rates of injury, fall, muscle relaxation, muscle pain, and weakness. Serum 25-hydroxy vitamin D $(25(\mathrm{OH}) \mathrm{D})$ levels are very important for maintaining and improving optimal performance in football players. The formation of free radicals and oxidative stress during exercise is known to affect optimal performance and recovery period after exercise. The aim of the study was to determine serum $25(\mathrm{OH}) \mathrm{D}$ and total antioxidant capacity of professional football players.

Methods: The study group consists of 56 professional football players ( 26 players from the first team, 30 players from the academy team) playing in Giresunspor Football Club. The control group consisted of 30 volunteer healthy male subjects. The SPSS 21 package program was used to calculate and interpret the survey data applied face to face to the study group. In addition, the body composition of the players was determined by the InBody 230 device which works with the principle of bioelectric impedance analysis (BIA). Serum $25(\mathrm{OH}) \mathrm{D}$ levels of the football players were compared with reference values $(\geq 30 \mathrm{ng} / \mathrm{mL})$. Serum $25(\mathrm{OH}) \mathrm{D}$ levels were determined by immunoassay method on the Roche Cobas e411 branded test analyzer. Serum total antioxidant capacity was compared with 30 healthy volunteers in the control group. Total antioxidant capacity measurements were studied with the ready-to-use kit. The method previously described for the kit has been applied to Architect c 8000 clinical chemistry autoanalyzer.

Results: As a result of the study, mean serum 25(OH)D levels of the players were determined as $31.68 \mathrm{ng} /$ $\mathrm{mL}$. The mean serum antioxidant capacity of the participants was found to be $1.97 \mathrm{mmol}$ Trolox Equiv/L. The mean serum antioxidant capacity of the control group was $1.94 \mathrm{mmol}$ Trolox Equiv/L.

Conclusion: Mean serum 25(OH)D levels of the players were within the reference range $(\geq 30 \mathrm{ng} / \mathrm{mL})$.

There is an increase in metabolic rate during training, which leads to a rapid release of free radicals. Despite this thought, there was no significant difference in serum total antioxidant capacity between the study and control groups.
\end{abstract}

Key words: Football players, antioxidants, vitamin D

Suggested Citation: Bahar I, Aysegul C. Definition of the total antioxidant capacity and vitamin D levels in professional athletes who play football in Giresunspor. Mid Blac Sea J Health Sci, 2021; 7(1):42-48

\begin{tabular}{lc}
\hline Address for correspondence/reprints: & E-mail: dyt.irembahar@gmail.com \\
Irem Bahar & $\begin{array}{c}\text { Note: This study was presented as an oral presentation at the } \\
\text { international congress (ICATES, 2019) held in Lviv, Ukraine } \\
\text { on September 18-20, 2019. }\end{array}$
\end{tabular}

Telephone number: +90 (531) 8133739 


\section{Introduction}

Nutrition, health protection, growth, the use of nutrients for the continuity of life are among the priorities of human needs (1).

When nutritioning of athletes is mentioned, firstly athletes who train regularly are considered. Since these individuals use their physical powers at maximum level, they constitute a field of study for researchers. In most sports, there is an important relationship between nutrition and performance. Nutrition is extremely important for maximal performance. However, the diet varies greatly according to the athlete and the sports branch. Many genetic and environmental factors affect the athlete's performance. However, it is very difficult for the athlete to reach maximal potential without the necessary nutrition; performance cannot be elevated, training cannot be done adequately, the athlete becomes more susceptible to infection and disability (2).

Developments in industry and technology have resulted in people spending a significant portion of their time in buildings, cars, and sun-protected spaces. Vitamin D deficiency is now a worldwide problem and is referred to as a pandemic (3).

The effect of total antioxidant capacity on the healthy and long life of people has started to be examined in recent studies. Radicals are also products produced as a result of metabolism, including secretions by the cell-based defense system such as medicines and chemicals taken. The best-known feature of these products is their extremely reactive properties. They can react with any substance (especially in living tissue) (4).

Free radicals damage the cell membrane, proteins, lipids, DNA and nucleic acids in the cell structure; as a result, it causes many diseases such as cancer, diabetes, coronary diseases, liver damage, and cataracts. The organism has antioxidant defense mechanisms against free radical damage caused by endogenous or exogenous sources. These mechanisms inhibit the reaction caused by free radicals (4).

The aim of this study is to determine the serum $25(\mathrm{OH}) \mathrm{D}$ levels of the football players living here due to lack of sun's rays the climatic conditions of Giresun, a province located in the Black Sea Region in Turkey. Also, based on the idea that regular training of football players can produce more oxidants than normal healthy individuals, it is important to determine their total antioxidant capacity in their biological systems. Thus, with the data obtained, football players and normal healthy individuals were compared.
Vitamin D

95\% of the vitamin D requirement is met by the effect of ultraviolet rays on the skin. The form of Vitamin D synthesized in the skin is cholecalciferol (Vitamin D3) and the diet is taken from ergocalciferol (Vitamin D2).

Vitamin D is a very important molecule, also called hormone, which regulates many mechanisms in the organism. Fat-soluble sterol structure that acts directly or indirectly in many mechanisms supporting bone and muscle development in the body (5). Vitamin D intake is limited. Mostly found in oily fish such as salmon, mackerel, sardine and egg yolk (6).

Serum $25(\mathrm{OH}) \mathrm{D}$ level should be performed to determine whether the vitamin $\mathrm{D}$ level is normal, low or high in individuals.

Serum 25(OH)D Levels (7);

$\leq 10 \mathrm{ng} / \mathrm{mL}$; significant deficiency,

$10-20 \mathrm{ng} / \mathrm{mL}$; lack,

20-30 ng/mL; moderate deficiency or inadequacy, $\geq 30 \mathrm{ng} / \mathrm{mL}$; enough,

$40-50 \mathrm{ng} / \mathrm{mL}$; ideal,

$>150 \mathrm{ng} / \mathrm{mL}$; toxic.

\section{Antioxidants}

Antioxidants are known as molecules that directly affect oxidant molecules that exceed a certain level and neutralize them. The organism protects itself against oxidative damage by enzymatic (superoxide dismutase (SOD), catalase and glutathione peroxidase (GSH-Px), etc.) and non-enzymatic (vitamin C, vitamin E, flavonoids and coenzyme Q10, etc.) antioxidant systems (8).

Many factors such as exercise and aging affect the oxidative stress and antioxidant defense system (911).

\section{Methods}

The study group consists of 56 professional football players ( 26 players from the first team, 30 players from the academy team) playing in Giresunspor Football Club. A survey including general characteristics (age, gender, educational status, illness, etc.), cigarette/alcohol use and nutritional supplement use was applied to the participants. The control group consisted of 30 male volunteers who were matched with the study group in terms of age and gender and without any diagnosis of chronic disease (diabetes, hypertension, ulcerative colitis, etc.). Samples of this study were collected between August 2017 and November 2017.

Blood samples were collected after 12-hour fasting to determine the serum 25-hydroxy vitamin D $(25(\mathrm{OH}) \mathrm{D})$ level of the players and the serum total 
antioxidant capacity analysis of the players and the control group. Serum 25(OH)D levels were not measured in the control group, serum $25(\mathrm{OH}) \mathrm{D}$ levels of the players were compared with reference values $(\geq 30 \mathrm{ng} / \mathrm{mL}$ ) and total antioxidant capacity was compared with healthy individuals in the control group. In addition, some anthropometric measurements were taken from football players. Body composition was determined by the InBody 230 device, which operates on the BIA principle.

All participants informed and signed a voluntary consent form.

For the sample size, according to the mean and standard deviation obtained by taking the average values of the 3 studies taken as basis, it was determined that 56 individuals were sufficient according to the $85 \%$ test power and $5 \%$ error value.

This study was approved by Ordu University Ethics Committee on 05.04.2018 in line with the decision numbered 2018-63.

\section{Biochemical Analysis}

Serum 25(OH)D levels were determined by immunoassay method on the Roche Cobas e411 branded test analyzer. The principle of this test is the competition principle.

Total antioxidant capacity (TAS) was evaluated on the basis of the conversion of the antioxidants in the sample to the colorless reduced ABTS form of the radical blue-green 2,2'-azino-bis (3ethylbenzothiazoline-6-sulfonic acid) cation (ABTS * +). The sample TAS level is related to the absorbance change at $660 \mathrm{~nm}$. For calibration, a vitamin $\mathrm{E}$ analogue $( \pm)$-6-hydroxy-2,5,7,8tetramethylchromane-2-carboxylic acid (Trolox Equivalent) was used. The results are expressed in mmol Trolox Equiv./L.

\section{Statistical Analysis}

SPSS 21 package program was used for data analysis. Descriptive statistics such as statistics, rate, mean and standard deviation of football players were made. Nonparametric tests were used to compare the groups of quantitative data due to a lack of normality assumption. Mann-Whitney U tests were used to compare two groups.

\section{Results}

The data in this study were obtained from professional football players at Giresunspor Football Club. Information gathered as a result of the survey of players. Serum $25(\mathrm{OH}) \mathrm{D}$ level was compared with reference values $(\geq 30 \mathrm{ng} / \mathrm{mL})$. In addition, serum total antioxidant capacity; the total antioxidant capacity in the serum of 30 healthy, non-football players, male subjects was compared.

Table.1. Average of the players participating in the study

\begin{tabular}{|c|c|}
\hline Variables & Mean \pm SD \\
\hline Age (year) & $22,96 \pm 5,26$ \\
\hline BMI $\left(\mathrm{kg} / \mathrm{m}^{2}\right)$ & $21,40 \pm 0,33$ \\
\hline Fat Percent (\%) & $9,06 \pm 2,59$ \\
\hline $\begin{array}{l}\text { Serum 25-Hydroxy Vitamin D Levels } \\
(\mathrm{ng} / \mathrm{mL})\end{array}$ & $31,68 \pm 12,69$ \\
\hline Variables & $(\%)$ \\
\hline Smoking & 5,4 \\
\hline Alcohol Consumption & 8,9 \\
\hline Nutritional Supplementation & 42,9 \\
\hline Whey Protein & 21,4 \\
\hline $\begin{array}{llll}\text { BCAA } & \text { (Branched Chain } & \text { Amino } \\
\text { Acids) } & & & \\
\end{array}$ & 23,2 \\
\hline L-Carnitine & 3,6 \\
\hline CLA(Conjugated Linoleic Acids) & 3,6 \\
\hline Creatine & 5,4 \\
\hline Vitamin B & 0 \\
\hline Vitamin D & 5,4 \\
\hline Multivitamin Usage & 25 \\
\hline Non-Routine Training & 48,2 \\
\hline Fitness & 33,9 \\
\hline Abdominal Training & 19,6 \\
\hline Weight Training & 1,8 \\
\hline Strength Training & 3,6 \\
\hline Endurance Training & 5,4 \\
\hline
\end{tabular}

It was determined that approximately 54\% of the players in the academy teams ( 90 minutes of training) and $46 \%$ of them in the first team (120 minutes of training) (Figure.1).

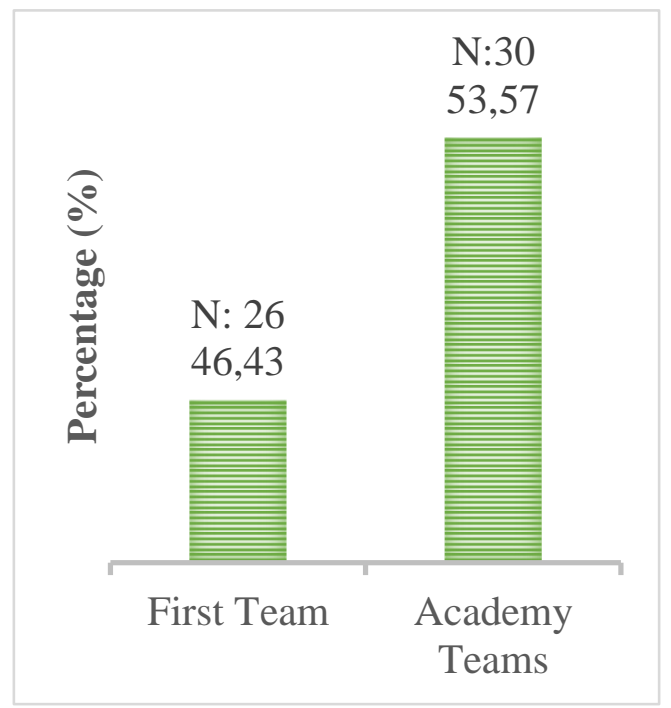

Figure.1. Distribution of players participating in the study according to the type of team

Approximately $52 \%$ of serum $25(\mathrm{OH}) \mathrm{D}$ levels of the players were within the reference range $(\geq 30$ $\mathrm{ng} / \mathrm{mL})$. Serum $25(\mathrm{OH}) \mathrm{D}$ levels were found to be below the reference range in $48.21 \%$ (Figure 2). 


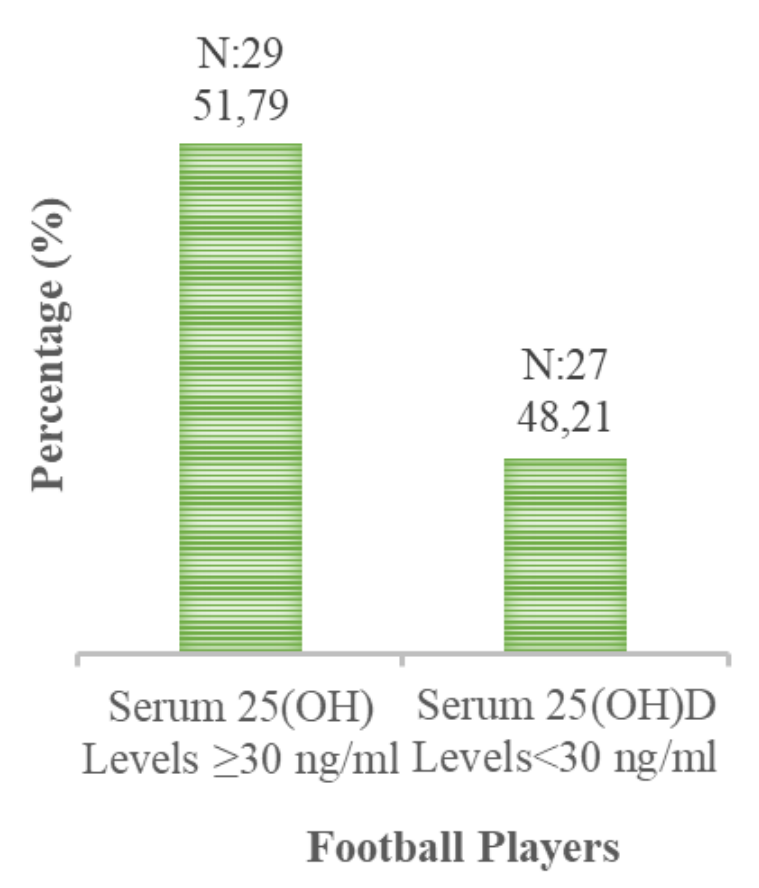

Figure.2. Distribution of participating players according to serum 25(OH)D levels.

According to the results, it was observed that there was a difference in serum $25(\mathrm{OH}) \mathrm{D}$ levels measured according to the type of team in which the players were assigned $(\mathrm{p}=0.042)$. While the median value of serum $25(\mathrm{OH}) \mathrm{D}$ was $29.4 \mathrm{ng} / \mathrm{mL}$ in academy teams; serum $25(\mathrm{OH}) \mathrm{D}$ median value of the players in the first team was $33.56 \mathrm{ng} / \mathrm{mL}$. Accordingly, players in the first team had statistically significantly higher serum 25(OH)D values (Table 2$)$.

Table.2. Comparison of serum $25(\mathrm{OH})$ D levels according to the type of team in which the players participated in the study

\begin{tabular}{lllll}
\hline Team Type & N & $\begin{array}{l}\text { Mean } \\
(\min -m a x)\end{array}$ & U & p \\
\hline Academy Teams & 30 & $\begin{array}{l}29,40 \\
(9-90)\end{array}$ & 266,50 & 0,042 \\
& & & \\
First Team & 26 & $\begin{array}{l}33,56 \\
(18,26-60,01)\end{array}$ & & \\
\hline
\end{tabular}

*Mann-Whitney U test was used.

Table.3. Comparison of serum total antioxidant capacity according to the type of team in which the players participated in the study

\begin{tabular}{lclll}
\hline Team Type & N & $\begin{array}{l}\text { Mean } \\
(\text { min-max })\end{array}$ & U & p \\
\hline Academy Teams & 30 & $\begin{array}{l}2,01 \\
(1,75-2,56)\end{array}$ & 266 & 0,041 \\
First Team & 26 & $\begin{array}{l}1,90 \\
(1,70-2,21)\end{array}$ & & \\
\hline
\end{tabular}

* Mann-Whitney U test was used.
According to the results, it was found that there was a statistically significant difference in the total antioxidant capacity of the players measured according to the type of team they were assigned $(\mathrm{p}=$ $0.041)$. The median value of the total antioxidant capacity of the players in the academy teams was 2.01 mmol Trolox Equiv/L; serum total antioxidant capacity of the players in the first team median value of $1.90 \mathrm{mmol}$ Trolox Equiv/L was determined. Players in the first team had statistically significantly lower serum total antioxidant capacity values (Table $3)$.

According to the results, it was found that there was a difference between the nutritional status of the players and the serum $25(\mathrm{OH}) \mathrm{D}$ levels measured $(\mathrm{p}=$ $0.001)$. The median value of serum $25(\mathrm{OH}) \mathrm{D}$ was $35.82 \mathrm{ng} / \mathrm{mL}$ in nutritional supplements; the median value of serum $25(\mathrm{OH}) \mathrm{D}$ was $26.14 \mathrm{ng} / \mathrm{mL}$ in football players without nutritional supplementation. Players using nutritional supplements had statistically significantly higher serum 25(OH)D levels (Table 4).

According to the results, there was no difference between the nutritional status of the players and the total antioxidant capacity $(\mathrm{p}=0,101)$ (Table 5).

The total antioxidant capacity of the players in the study was $1.97 \mathrm{mmol}$ Trolox Equiv/L and $1.94 \mathrm{mmol}$ Trolox Equiv/L in the control group. According to the results, there was no difference in serum total antioxidant capacity between football players and control group $(\mathrm{p}=0.657)$ (Table 6)..

Table.4. Relationship between nutritional supplementation and serum $25(\mathrm{OH}) \mathrm{D}$ levels of the participating players

\begin{tabular}{lllll}
\hline $\begin{array}{l}\text { Nutritional } \\
\text { Supplementation }\end{array}$ & $\mathbf{N}$ & $\begin{array}{l}\text { Mean } \\
(\mathbf{m i n}-\mathbf{m a x})\end{array}$ & $\mathbf{U}$ & $\mathbf{P}$ \\
\hline Yes & 24 & $\begin{array}{l}35,82 \\
(23,45-\end{array}$ & 187 & 0,001 \\
& & $\begin{array}{l}60,01) \\
26,135\end{array}$ & & \\
No & 32 & $26-90)$ & & \\
& & & & \\
\hline
\end{tabular}

*Mann-Whitney U test was used.

Table.5. Relationship between nutritional supplementation and serum total antioxidant capacity

\begin{tabular}{lclll}
\hline $\begin{array}{l}\text { Nutritional } \\
\text { Supplementation }\end{array}$ & N & $\begin{array}{l}\text { Mean } \\
\text { (min- } \\
\text { max) }\end{array}$ & U & P \\
\hline Yes & 24 & 1,945 & 286 & 0,101 \\
& & $\begin{array}{l}(1,70- \\
2,21)\end{array}$ & & \\
No & 32 & 2,025 & & \\
& & $(1,74-$ & & \\
& & $2,56)$ & & \\
\hline
\end{tabular}

*Mann-Whitney U test was used. 
Table.6. Relationship between serum total antioxidant capacity of the football players and control group

\begin{tabular}{lllll}
\hline $\begin{array}{l}\text { Football } \\
\text { Player }\end{array}$ & $\mathbf{N}$ & $\begin{array}{l}\text { Mean } \\
(\text { min-max) }\end{array}$ & U & P \\
\hline Yes & 56 & $\begin{array}{l}1,97 \\
(1,70-2,56)\end{array}$ & 791 & 0,657 \\
No & 30 & $\begin{array}{l}1,94 \\
(1,62-2,31)\end{array}$ & & \\
\hline
\end{tabular}

*Mann-Whitney U test was used.

\section{Discussion}

In this study, serum total antioxidant capacity and serum $25(\mathrm{OH}) \mathrm{D}$ levels in professional athletes who play in Giresunspor Football Club were determined. Approximately $54 \%$ of the players participating in the study were from the academy teams (90 minutes training) and $46 \%$ were from the first team (120 minutes training). According to the data obtained from the survey; the average age of the players participating in the study is 22.9. In addition, mean BMI (body mass index) and fat percentage respectively; $21.40 \mathrm{~kg} / \mathrm{m} 2$ and $9.06 \%$.

The rate of using the nutritional support of the players participating in the study is $42.9 \%$. The most preferred nutritional supplement is multivitamin with $25 \%$. Nutritional supplements are products that athletes use to improve exercise performance. The use of such nutritional supplements, which are not considered doping, is quite common to improve exercise performance as well as ranking competition efficiency. The majority of the players participating in the study prefer to use vitamins in the form of multivitamins rather than using vitamins separately to accelerate recovery after training. Due to free radicals released as a result of excessive exercise, they meet the need for antioxidant vitamins and vitamin B that play a role in energy metabolism. It is also known that such vitamins increase endurance in athletes.

In this study, serum $25(\mathrm{OH}) \mathrm{D}$ levels were found to be higher in first team compared to the academy teams. This result can be explained by the fact that the training time is longer and that they benefit more from the sun's rays. Maroon et al. in their study, the average value of serum $25(\mathrm{OH}) \mathrm{D}$ levels in football players in the United States National League was found to be $27.4 \mathrm{ng} / \mathrm{mL}$. The same study showed that serum $25(\mathrm{OH}) \mathrm{D}$ levels were lower in black football players than in white football players (12). Krzywanski et al. in their study, the average value of vitamin D levels of the indoor athletes in the Polish athletes found to be $27 \mathrm{ng} / \mathrm{mL}$ (13). A similar result was found by Bauer et al. also shown in their study on athletes playing handball in Germany (14). Accordingly, lower serum 25(OH)D levels are observed in indoor athletes.
The relationship between nutritional supplementation and serum $25(\mathrm{OH}) \mathrm{D}$ levels of the participating players was examined. $25(\mathrm{OH}) \mathrm{D}$ levels were found to be higher in football players with nutritional supplements. This result was associated with the content of nutritional support used by football players. In addition, it was determined that the use of nutritional supplements was more common in the first team and this result positively affected serum vitamin D levels. The increase in vitamin D levels has positive effects on the musculoskeletal system. Adequate levels of vitamin D have a positive effect on protein synthesis, muscle strength, jumping height/speed, exercise capacity and physical performance in athletes. At the same time, stress fracture rates decreased in athletes with sufficient serum $25(\mathrm{OH}) \mathrm{D}$ levels $(15,16,17,18)$.

Sufficient serum 25(OH)D levels; reduces injury, falls, muscle relaxation, muscle pain, and weakness. Vitamin D is effective to maintain and increase optimal performance in athletes (19). Although studies investigating the effects of vitamin $D$ on performance are limited, vitamin $\mathrm{D}$ is great importance for preventing muscle injuries and preventing stress fractures.

Serum total antioxidant capacity were found to be higher in academy teams compared to the first team. In general, during training, the amount of erythrocytes circulating, circulation rate, arteriovenous oxygen difference in relation to the severity of muscle activity; that is, an increase in the amount of oxygen released in the active muscle and metabolic rate (20). This leads to a faster release of free radicals. Based on this information, the free radical formation is higher since the first team is training longer (120 minutes training); therefore, the total antioxidant capacity of serum is lower than that of the academy teams players (90 minutes training).

The relationship between nutritional supplementation and serum total antioxidant capacity of the players in the study was examined. There was no relationship between nutritional supplementation and serum total antioxidant capacity.

The serum total antioxidant capacity was not different between the players and the control group. In contrast to this study, Brites et al. in a study on football players, serum total antioxidant capacity of football players was found to be $25 \%$ more than the control group (21). 


\section{Limitations}

Limitations of the study can be listed as: serum vitamin D levels of professional football players (first team and academy teams) playing in Giresunspor football club were compared with reference value. Serum vitamin D measurement and survey were not applied to the control group.

\section{Conclusions}

This study is the first study conducted on football players determination of the serum total antioxidant capacity and serum vitamin D levels in Turkey.

\section{Acknowledgment}

This research was financially supported by the Scientific Project Office of Giresun University (SAĞBAP-C-150616-127).

Ethics Committee Approval: Ethics committee approval was received for this study from Ordu University Clinical Research Ethics Committee (KAEK 2018-63).

Peer-review: Externally peer-reviewed.

Author Contributions:

Concept: I.B, A.Ç, Design: I.B, A.Ç, Literature Search: I.B, Data Collection and Processing: I.B, Analysis or Interpretation: I.B, Writing: I.B, A.C.

Conflict of Interest: No conflict of interest was declared by the authors.

Financial Disclosure: This research was financially supported by the Scientific Project Office of Giresun University (SAĞ-BAP-C-150616-127).

\section{References}

1. Baysal A. Nutrition. Hatipoğlu Bookstore, 2009, Ankara.

2. Ersoy G. Nutrition for exercise and sports. Nobel Bookstore, 2012, Ankara.

3. Holick M.F. and Chen T.C. Vitamin D deficiency: a worldwide problem with consequences. American Journal of Clinical Nutrition, 2008; 87: 1080-1086.

4. Velioglu S. Effects of Natural Antioxidants on Human Health. Food Journal, 2000; 25(3): 167176.

5. Sercan C. Yavuzsoy E. Yuksel I. Can R. Oktay S. Kirac D. and Ulucan K. Importance of Vitamin D and Receptor in Athletic Health and Athletic Performance. University of Marmara, Journal of the Institude of Health Sciences, 2015; 5(4): 259264.
6. Holick M.F. Resurrection of vitamin D deficiency and rickets. Journal of Clinical Investigation, 2006; 116: 2062-2072.

7. Lavie C.J. Lee J.H. and Milani R.V. Vitamin D and cardiovascular disease will it live up to it is hype? Journal of the American College of Cardiology, 2011; 58: 1547-1556.

8. Halliwell B. and Gutteridge J.M.C. Free radicals in biology and medicine. Oxford University Press, New York, USA, 2000; 534-537.

9. Netzer N. Gatterer H. Faulhaber M. Burtscher M. Pramsohler S. and Pesta D. Hypoxia, oxidative stress and fat. Biomolecules, 2015; 5: 1143-1150.

10.Belviranli $M$. and Okudan N. Well-known antioxidants and newcomers in sport nutrition: coenzyme Q-10 quercetin resveratrol pterostilbene pycnogenol and astaxanthin. In: antioxidants in sports nutrition (Lamprecht $\mathrm{M}$. Ed.) Boca Raton (FL): CRC Press/ Taylor\&Francis, 2015; 79-102.

11.Jones D.P. Redox theory of aging. Redox Biology, 2015; 5: 71-79.

12.Maroon J.C. Mathyssek C.M. Bost J.W. et al. Vitamin $\mathrm{D}$ profile in national football league players. Am J Sport Med, 2015; 43: 1241-1245.

13.Krzywanski J. Mikulski T. Krysztofiak H. et al. Seasonal vitamin D status in Polish elite athletes in relation to sun exposure and oral supplementation. PLOS One, 2016; 11: e0164395.

14.Bauer P. Henni S. Dörr O. et al. High prevalence of vitamin D insufficiency in professional handball athletes. The Physician and Sports Medicine, 2018; DOI: 10.1080/00913847.2018.1520055.

15.Pfeifer M. Begerow B. and Minne H.W. Vitamin $\mathrm{D}$ and muscle function (review). Osteoporosis International, 2002; 13: 187-194.

16.Larson-Meyer D.E. and Willis K.S. Vitamin D and athletes (review). Current Sports Medicine Reports, 2010; 9: 220-226.

17.Rejnmark L. Effects of vitamin D on muscle function and performance a review of evidence from randomized controlled trials. Therapeutic Advances in Chronic Disease, 2011; 2: 25-37.

18. Ogan D. and Pritchett K. Vitamin D and the athlete: risks, recommendations and benefits. Nutrients, 2013; 5: 1856-1858.

19. Chatterjee S. Mondal S. Borman A.S. and Konar A. Vitamin D, optimal health and athletic performance: a review study. International Journal of Food Sciences and Nutrition, 2014; 3: 526-533. 
20.Ji L.L. and Leichtweis S. Exercise and Oxidative Stress: Sources of Free Radicals and Their Impact on Antioxidant Systems. Age (Omaha), 1997; 20(2): 91-106.

21.Brites F.D. Evelson P.A. Christiansen M.G. et al. Soccer players under regular training show oxidative stress but an improved plasma antioxidant status. Clinical Science, 1999; 96(4): 381-385. 